\title{
Interaction between Dopaminergic and Angiotensinergic Systems on Thirst in Adult Male Rats
}

\author{
Zohreh Sharifkhodaei $^{1}$, Nasser Naghdi ${ }^{2 *}$, Shahrbanoo Oryan ${ }^{1}$ \\ ${ }^{1}$ Department of Biology, Science Faculty, Tarbiat Moallem University, Tehran, Iran; ${ }^{2}$ Department of Physiology \& Pharmacology, \\ Pasteur Institute, Tehran, Iran. \\ Email: zohrehsharif@zoology.ubc.ca, ${ }^{*}$ naghdi@pasteur.ac.ir, sh_oryan@saba.tmu.ac.ir
}

Received December $16^{\text {th }}, 2011$; revised January $30^{\text {th }}, 2012$; accepted February $9^{\text {th }}, 2012$

\begin{abstract}
Thirst, which provides the motivation to drink, is an important component of the coordinated sequence of physiological responses that maintain the volume and composition of body fluids. Special structures in the central nervous system like periventricular organs detect changes in these parameters continuously. The present study investigated the interaction between dopaminergic and angiotensinergic systems on water intake in adult male rats. Intracerebroventricular (ICV) injections were carried out in all experiments after $24 \mathrm{~h}$ deprivation of water intake. After the deprivation interval, the volume of consumed water was measured for $1 \mathrm{~h}$. Administration the angiotensinergic $\left(\mathrm{AT}_{1}\right)$ receptor antagonist Losar$\tan (45 \mu \mathrm{g} / \mathrm{rat})$, and the dopaminergic antagonist Chlorpromazine (40 $\mu \mathrm{g} / \mathrm{rat})$ significantly decreased water intake when compared to saline-treated controls. In contrast, ICV microinjection of the dopaminergic agonist Bromocriptine (10 $\mu \mathrm{g} / \mathrm{rat})$ significantly increased water intake when compared to saline-treated controls. ICV injection of Bromocriptine 15 min after Losartan administration was able to attenuate the inhibitory effect of Losartan on water intake, whereas administration of Chlorpromazine $15 \mathrm{~min}$ after Losartan was unable to change the Losartan effect. These results suggest that the dopaminergic system interactions with the angiotensinergic system to regulate water intake through circumventricular organs. Dopaminergic and angiotensinergic neurons can monitor and regulate water intake via the stimulatory and inhibitory effects on each other, respectively.
\end{abstract}

Keywords: Water Intake; Drinking; Dopaminergic Receptors; Angiotensinergic Receptors; Thirst; Rats

\section{Introduction}

Thirst and salt appetite are important behaviors that help mammals to regulate plasma osmolarity, blood volume and blood pressure [1,2]. Thirst, which provides the motivation to drink, is an important component of the coordinated sequence of physiological responses that maintain the volume and composition of body fluids [3]. The homeostatic regulation of fluid intake by the brain is multifactorial: Osmotic, ionic, hormonal, and nervous signals converge on, and are integrated within, the central nervous system [3]. Specialized structures located both in the central nervous system and in strategic peripheral sites detect changes in these parameters continuously and accurately [2]. There is evidence that some osmoreceptors and osmoreceptive neurons are situated in the preoptic/hypothalamic region of the brain, rostral tissue in the anterior wall of the third ventricle (AV3V) [4], fourth and lateral ventricles [5], dorsal part of the organum vasculosum of the lamina terminalis (OVLT), the periphery of the su-

"Corresponding author. fornical organ (SFO) [3], median preoptic nucleus (MnPO) [4], lateral hypothalamic area and the hypothalamic paraventricular nucleus $[3,6]$. The MnPO receives afferent neural input from neurons in both the SFO and the OVLT and may integrate neural signals coming from osmoreceptive neurons in these circumventricular organs with visceral sensory inflow from the hindbrain [3]. Afferent input form the cardiopulmonary and arterial baroreceptors is carried to the brain by the IXth and Xth cranial nerves, with most of these nerves terminating in the nucleus of the solitary tract (NST) [7]. The nucleus tractus solitarius and the area postrema signal to lateral parabranchial nucleus that in turn signal to median preoptic nucleus. In addition, the area postrema and nucleus tractus solitarius also signal directly to subfornical organ [3]. Based on information obtained by these sensors, the central nervous system initiates responses including the stimulation or the inhibition of water and salt intake [1,2].

Previous studies have shown that a rapid and large intake volume of water and an increase in blood pressure occur immediately after the injection of angiotensin II into 
the cerebral ventricles or the preoptic region. This is a clear indication that central angiotensinergic system could cause thirst. Furthermore, centrally administered Ang II receptor antagonists are known to eliminate the drinking response [8].

Moreover, $\mathrm{MnPO}$ neurons are stimulated by angiotensinergic projection originating from the SFO and project towards vasopressinergic and oxytocinergic neurons of the PVN. When Ang II injected directly into these areas, an increase in water intake followed by an increase of sodium consumption subsequently occurs [9].

Also some studies indicate that dopaminergic neurons are highly concentrated in sev eral locations including substantia nigra (SN) [10], ventral tegmental area (VTA) [10], median eminence, hypothalamic [10,11], accumbens, caudate nuclei $[12,13]$ and amygdala [12]. The data demonstrate that dopamine is required within the CNS for numerous roles including the control of water intake $[11,13]$, food intake [11,12], locomotor activity [12], cognitive processes, learning task [12], and anxiety [12] adaptive situation. Other studies indicate that activation of dopaminergic neurons within the central thirst-related system is crucial for initiating physiological events underlying drinking behavior [14]. Dipsogenic signals generated by AII at the POA are transferred to the SFO through the catecholaminergic nerve fibers [15]. Extensive studies [12] demonstrate that the most effective site for producing adipsia is an intermediate zone between the substantia nigra and VTA. Additionally, the nigrostriatal, caudate and accumbens nuclei [13] and the lateral hypothalamus [11] are involved in regulation of water intake.

Previous research has shown that intracranial injections of DA antagonist significantly reduce water intake and block angiotensin-induced drinking [16]. $\mathrm{D}_{1}$ receptor antagonists (SCH 23390) substantially reduce water intake and have greater role in control of water intake. Antidopaminergic agents (haloperidol) with pronounced antidopaminergic actions on $\mathrm{D}_{2}$ receptors reduce the water intake of rats [13]. DA agonist administration in the lateral hypothalamus reduce water intake and DA antagonist promote drinking [17].

In the present study, we investigate the interaction between the dopaminergic and angiotensinergic systems on water intake in adult male rats specifically regarding the role of the central angiotensinergic and dopaminergic systems on water deprivation induced thirst.

\section{Materials and Methods}

\subsection{Animals}

Adult male Wistar rats (200 - $250 \mathrm{~g}$ ) were obtained from the breeding colony of Tarbiat Moallem University of Tehran. Rats were housed three per cage, but one day before test day one per cage, in a temperature $\left(23^{\circ} \mathrm{C} \pm 1^{\circ} \mathrm{C}\right)$ con- trolled room that was maintained on a 12 hour on: 12 hour off light cycle (light on at 07:00 am). Rats had unrestricted access to food and water in their home cage. The type of food was pellet and it was purchased from Khorak Dam Pars Co. in Iran.

These animal experiments were carried out in accordance with recommendations from the declaration of Helsinki and the internationally accepted principles for the use of experimental animals.

\subsection{Surgical Procedures}

The rats were anesthetized with ketamine-xylazine (100 $\mathrm{mg} / \mathrm{kg}$ ketamine $5 \mathrm{mg} / \mathrm{kg}$ xylazine). The skull was leveled between bregma and lambda. A stainless steel 21gauge guide cannula $(0.8 \mathrm{~mm})$ was implanted above the lateral cerebral ventricle using coordinates from the atlas of Paxinos and Watson at least $5-7$ days before testing. The coordinates used were $0.8 \mathrm{~mm}$ posterior to the bregma, $1.3 \mathrm{~mm}$ lateral to the midline and $3.4 \mathrm{~mm}$ below the top of the skull. The cannula was fixed to the skull using one screw and dental acrylic.

\subsection{Microinjection Procedure}

Intracerebroventricular (ICV) injections were made via guide cannulae with injection needles (27-gauge) that were connected by polyethylene tubing to a $10 \mu 1$ Hamilton microsyringe. The injections $(0.5 \mu \mathrm{l}$ total volume $)$ were delivered over two minutes with a syringe pump, and the injection needles (extending $1.5 \mathrm{~mm}$ from the end of the guide cannulae) were left in place an additional minute before they were slowly withdrawn.

\subsection{Drugs}

The drugs included Bromocriptine methanesulfonate (Hakim Pharmaceutical company, Iran), a dopaminergic $\mathrm{D}_{2}$ receptor agonist, Chlorpromazine hydrochloride (Sigma), a dopaminergic $\mathrm{D}_{2}$ receptor antagonist, and Losartan potassium (Sigma), an angiotensinergic $\mathrm{AT}_{1}$ receptor antagonist. All the drugs were dissolved in saline. The drugs were used (ICV) in a volume of $0.5 \mu 1 /$ rat.

\subsection{Experimental Procedures}

The experiments were performed in conscious freely moving rats $5-7$ days post surgery. Forty-eight adult male rats were divided into 18 groups of 6 rats per group. Group 1 received sham operations. Groups 2, 3, and 4 received Bromocriptine (5, 10, or $20 \mu \mathrm{g} / \mathrm{rat})$. Groups 6,7 , and 8 received Chlorpromazine (20, 40, or $80 \mu \mathrm{g} / \mathrm{rat})$. Groups 9 , 10 , and 11 received Losartan $(22.5,45$, or $90 \mu \mathrm{g} / \mathrm{rat})$. Group 13 received sham operations and two ICV injections of saline $15 \mathrm{~min}$ apart. Group 14 received Losartan $(45 \mu \mathrm{g} / \mathrm{rat}) 15 \mathrm{~min}$ after ICV injection of saline. Group 
15 received Bromocriptine (10 $\mu \mathrm{g} / \mathrm{rat}) 15 \mathrm{~min}$ after ICV injection of saline. Group 16 received Bromocriptine (10 $\mu \mathrm{g} / \mathrm{rat}) 15 \mathrm{~min}$ after ICV injection of Losartan $(45 \mu \mathrm{g} / \mathrm{rat})$. Group 17 received Chlorpromazine $(40 \mu \mathrm{g} / \mathrm{rat}) 15 \mathrm{~min}$ after ICV injection of saline. Group 18 received Chlorpromazine $(40 \mu \mathrm{g} / \mathrm{rat}) 15 \mathrm{~min}$ after ICV injection of Losartan $(45 \mu \mathrm{g} / \mathrm{rat})$.

All rats were deprived of water for $24 \mathrm{~h}$ prior to each test day. Food was available during deprivation period but not during the test period. The food pellets may have had an interaction with thirst; however this condition was similar for all animals and consequently had no effect on our results. After $24 \mathrm{~h}$ water deprivation, saline or drugs were injected (ICV) over a period of $90 \mathrm{~s}$, and water in graduated glass cylinders was returned to each cage. Groups received two injections: a control saline injection followed 15 min later by injection of a drug, or one drug followed $15 \mathrm{~min}$ later by another drug to determine the effect of the first drug on the response to the second. In the control groups with two injections, saline was injected $15 \mathrm{~min}$ before a second administration of saline. Immediately after the last injection, water intake was recorded for $1 \mathrm{~h}$ by reading from the graduated glass cylinder mounted on the wall of the cages. All experiments were conducted between 9 am and 11 am and each rat was tested only once.

The proposal was established and approved by the Research and Animal Ethical Committees of Tarbiat Moallem University,Tehran, Iran.

\subsection{Data Analysis}

Data are reported as one way ANOVA followed by Tukey or Dunnett to test statistical significance. Differences were considered significant at $\mathrm{p}<0.05$.

\subsection{Histology}

Following behavioral testing, animals were sacrificed by decapitation and the brains were removed and fixed in formalin. For histological examination of cannulae and injection placement in the lateral ventricle, $100 \mu \mathrm{m}$ thick sections were taken and cannulae and injection tracks were examined with light microscopy. Only data obtained from animals whose cannulae and injections were exactly placed in the lateral ventricle were included for analysis.

\section{Results}

Experiment 1: The effect of ICV injection of $D_{2}$ receptor agonist and antagonist at different doses on water intake in fluid-deprived rats.

Figure 1 shows the effect of ICV injection of Bromocriptine and Chlorpromazine at different doses on water intake in fluid-deprived rats. One way ANOVA analysis indicated that there was a significant increase in water intake at a dose of $10 \mu \mathrm{g} / \mathrm{rat}$ Bromocriptine $(\mathrm{p}<0.01)$ in comparison to saline-treated controls. F $(3,20)=6.427,(n=6)$. And there was a significant decrease in water intake at a dose of $40 \mu \mathrm{g} /$ rat Chlorpromazine $(\mathrm{p}<0.05)$ in comparison to

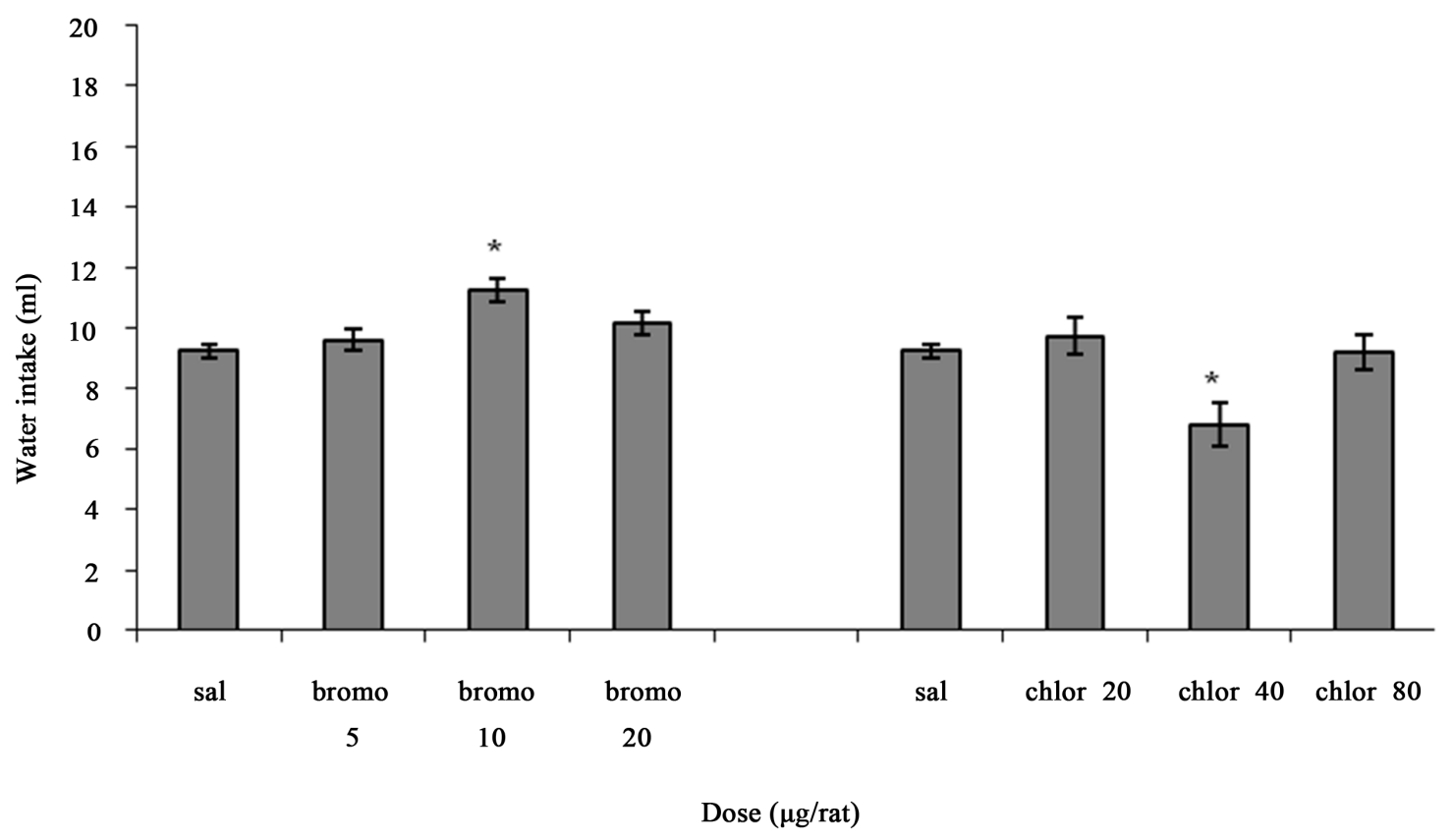

Figure 1. The effect of ICV microinjection of Bromocriptine and Chlorpromazine on water intake is shown. Rats were injected with saline or different doses of Bromocriptine $(5,10,20 \mu \mathrm{g} / \mathrm{rat})$ or Chlorpromazine $(20,40,80 \mu \mathrm{g} / \mathrm{rat})$ and water intake was measured for $1 \mathrm{~h}$. Columns represent the means \pm S.E.M. $(\mathrm{n}=6) .{ }^{* *} \mathbf{p}<0.01$ Bromocriptine $10 \mu \mathrm{g} /$ rat vs saline. ${ }^{*} \mathrm{p}<$ 0.05 Chlorpromazine $40 \mu \mathrm{g} / \mathrm{rat}$ vs saline. 
saline-treated controls. $\mathrm{F}(3,20)=5.100,(\mathrm{n}=6)$.

Experiment 2: The effect of ICV injection of $\mathrm{AT}_{1}$ receptor antagonist at different doses on water intake in fluid-deprived rats.

Figure 2 depicts the effect of ICV injection of Losar$\tan$ at different doses on water intake in fluid-deprived rats. One way ANOVA analysis indicated that there was a significant decrease in water intake at a dose of 45 $\mu \mathrm{g} / \mathrm{rat}(\mathrm{p}<0.05)$ in comparison to saline-treated controls. $\mathrm{F}(3,20)=4.271,(\mathrm{n}=6)$.

Experiment 3: The effect of ICV interaction between $A T_{1}$ receptor antagonist and $D_{2}$ receptor on water intake in fluid-deprived rats.

Figure 3 illustrates the effect of ICV interaction between Losartan, Bromocriptine and Chlorpromazine on water intake in fluid-deprived rats. One-way ANOVA analysis for ICV injection of Losartan and Bromocriptine alone or together indicated that there was a significant decrease at a dose of $45 \mu \mathrm{g} / \mathrm{rat}$ Losartan $(\mathrm{p}<0.05)$ and a significant increase at a dose of $10 \mu \mathrm{g} / \mathrm{rat}$ Bromocriptine $(\mathrm{p}<0.05)$ on water intake in comparison to salinetreated controls. ICV microinjection of Bromocriptine $15 \mathrm{~min}$ after Losartan administration $(p<0.001)$ could attenuate the inhibitory effect of Losartan on water intake significantly. $\mathrm{F}(3,20)=17.921,(\mathrm{n}=6)$.

One-way ANOVA analysis for ICV injection of Losartan and Chlorpromazine alone or together indicated that there was a significant decrease at a dose of $45 \mu \mathrm{g} / \mathrm{rat}$ Losartan $(\mathrm{p}<0.05)$, at a dose of $40 \mu \mathrm{g} /$ rat Chlorpromazine $(\mathrm{p}<0.05)$ and los/chloro $(\mathrm{p}<0.05)$ on water intake in comparison to saline-treated controls. F $(3,20)=4.197,(n=6)$. But ICV microinjection of Chlorpromazine 15 min after Losartan administration could not change the Losartan effect.

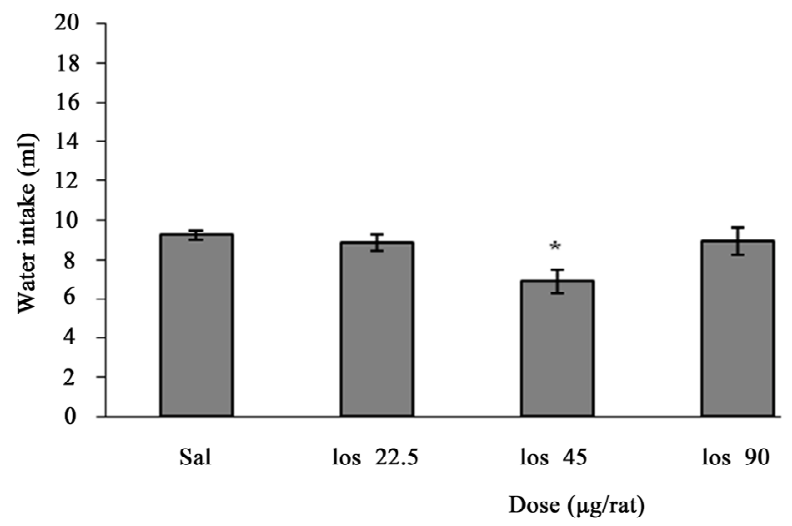

Figure 2. The effect of ICV microinjection of Losartan on water intake is shown. Rats were injected with saline or different doses of Losartan $(22.5,45,90 \mu \mathrm{g} / \mathrm{rat})$ and water intake were measured for $1 \mathrm{~h}$. Columns represent the means \pm S.E.M. $(n=6) .{ }^{*} p<0.05$ Losartan $45 \mu g /$ rat vs saline.

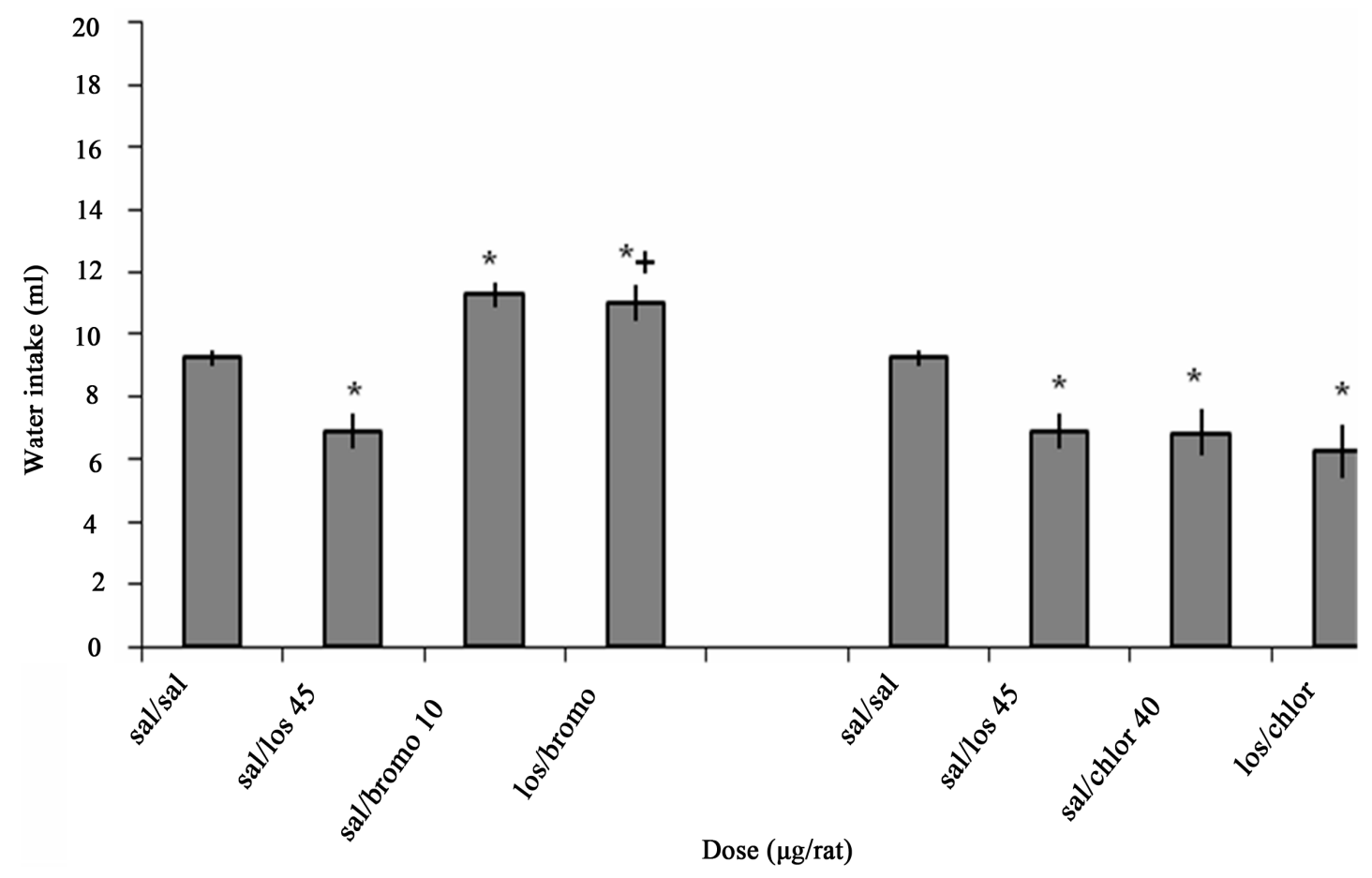

Figure 3. The effect of ICV interaction between Losartan, Bromocriptine and Chlorpromazine on water intake is shown. Rats

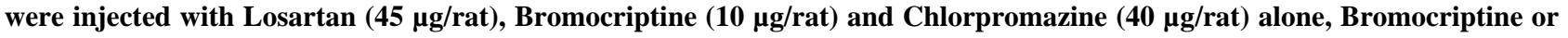
Chlorpromazine was administered 15 min after injection of Losartan. Water intake was measured for $1 \mathrm{~h}$. Columns represent the means \pm S.E.M. $\left(\mathrm{n}=6\right.$ ). ${ }^{*}$ p $<0.05$ sal/losartan $45 \mu \mathrm{g} / \mathrm{rat}$, sal/bromocriptine $10 \mu \mathrm{g} / \mathrm{rat}$, sal/chlorpromazine $40 \mu \mathrm{\mu g} / \mathrm{rat}$, los/chloro vs saline. $+\mathbf{p}<0.001$ los/bromo vs Losartan. 


\section{Discussion}

Our results indicatethat ICV microinjection of Losartan (45 $\mu \mathrm{g} / \mathrm{rat}$ ) and Chlorpromazine (40 $\mu \mathrm{g} / \mathrm{rat}$ ) significantly decreased water intake while, ICV microinjection of Bromocriptine $(10 \mu \mathrm{g} / \mathrm{rat})$ significantly increased it in comparison to saline-treated controls. ICV injection of Bromocriptine $15 \mathrm{~min}$ after Losartan administration was able to attenuate the inhibitory effect of Losartan on water intake while ICV injection of Chlorpromazine 15 min after Losar$\tan$ was unable to reverse the Losartan effect.

Losartan as an $\mathrm{AT}_{1}$ receptor antagonist decreased water intake in comparison to saline-treated controls.

$\mathrm{AT}_{1}$ receptors are concentrated in areas involved in central control of fluid homeostasis such as circumventricular organs and in brain areas related to blood pressure control such as paraventricular nucleus and nucleus of solitary tract [18]. Both hyperosmotic and hypovolemic signals could stimulate $\mathrm{AT}_{1}$ receptors $[19,20]$. The immunocytochemical localization of angiotensinogen in the brain has indicate it is present in neurons of forbrain, thalamus, hypothalamus, brain stem, magnocellular neurons of the paraventricular nucleus, supraoptic nucleus, nucleus of the solitary tract, and circumventricular organs [21]. Recent data from Justin et al. support the hypothesis that angiotensins may act as neurotransmitters and neuromodulators in the brain [22]. Angiotensinergic neurons in the circumventricular organs are connected with other regions in the brain linked to central blood pressure control and the regulation of body fluid homeostasis. Hyperosmotic condition stimulates the vasopressin (AVP) and oxytocin (OT) perikarya in PVN and SON nuclei [23]. Neurons localized in the SFO and OVLT project directly or indirectly, via an interposed synapse in the median preoptic nucleus, to the magnocellular part of the paraventricular nucleus and to the supraoptic nucleus, where vasopressin-synthesizing neurons are located. The excitability of the AVP neurons results in synthesis and release of vasopressin [24]. It is generally accepted that the central angiotensin II-induced cardiovascular and endocrine responses such as induction of drinking and dipsogenic effects, pressor response and release of AVP are mediated by $\mathrm{AT}_{1}$ receptors $[25,18]$. Furthermore, central injection of $\mathrm{AT}_{1}$ receptor antagonist, Losartan, blocks $\mathrm{AT}_{1}$ receptors and influences on central angiotensin mechanisms [24,26]. Infusion of Ang II into a lateral cerebral ventricle produce an increase in blood pressure [27,20,28], increase in mean arterial pressure [29,30], decrease in urine flow [27], regulate hydromineral balance [22], induce the pressor response [31], stimulate AVP and OT release $[20,28]$ and elevate RSNA (renal sympathetic nerve activity) [32]. Losartan blocks water intake in intracellular and extracellular dehydrated conditions, inhibits the release of AVP and OT, reduces RSNA response and antidiuretic action [5,32]. Therefore our results, along with those of other researchers, suggest that Losartan has an inhibitory effect on water intake.

Bromocriptine, a $\mathrm{D}_{2}$ receptor agonist, increased water intake whereas Chlorpromazine, a $\mathrm{D}_{2}$ receptor antagonist, decreased water intake in comparison to saline-treated controls.

The data demonstrated that the integrity of dopaminergic receptors is required for central control of water intake [11]. Osmotic signals could stimulate $\mathrm{D}_{2}$ receptors [33]. The stimulatory effect could be produced by dopamine acting on preventricular receptors [34]. Puigde et al. demonstrated that dopaminergic pathways control the AVP release [11]. Dopamine enhanced the firing of (oxytocin-secreting and vasopressin-secreting) neurons in supraoptic nucleus of rat. This action was antagonized by $\mathrm{D}_{2}$ receptor antagonists [35]. Microinjection of Dopamine in to lateral ventricles or third ventricle produced an increase in AVP concentration [34]. It is well established that dopamine and its agonists play an important role in cardiovascular, renal, hormonal and central nervous system regulation through stimulation of dopaminergic receptors. Bromocriptine a $\mathrm{D}_{2}$ receptor agonist produces a pressor response, stimulates the AVP release, and increases sympathetic tone, activity of the Renin-Aldosterone System and blood pressure [36,37]. $\mathrm{D}_{2}$ receptor antagonist like Chlorpromazine markedly inhibits the pressor response causes the hypotension and lowering of blood pressure, blunts the increase in urinary volume and sodium excretion [38, 39]. Bromocriptine was highly potent agonists at dopamine $D_{2}$ and $D_{3}$ receptors. It was ten times more potent at the dopamine $\mathrm{D}_{2}$ than at the dopamine $\mathrm{D}_{3}$ receptor [7]. Chlorpromazine is a very effective antagonist of $\mathrm{D}_{2}$ dopamine receptors, but it has also effect on a variety of receptors in the central nervous system such as $\mathrm{D}_{1}, \mathrm{D}_{2}$, $\mathrm{D}_{3}, \mathrm{D}_{4}$ receptors, serotonin receptors $\left(5-\mathrm{HT}_{1}\right.$ and $5-\mathrm{HT}_{2}$, leading to fall in blood pressure), histamine receptors ( $\mathrm{H1}$ receptors, fall in blood pressure) $\alpha_{1}$-and $\alpha_{2}$-adrenergic receptors (antisympathomimetic properties, lowering of blood pressure, reflex tachycardia), $\mathrm{M}_{1}$ and $\mathrm{M}_{2}$ muscarinic acetylcholine receptors (causing anticholinergic symptoms such as dry mouth, inability to urinate, sinus tachycardia. Because it acts on so many receptors, chlorpromazine is often referred to as a dirty drug [40]. Therefore it should be noted that Bromocriptine and Chlorpromazine are known to be involved in more than one receptor and Chlorpromazine interact with several systems, we cannot totally rule out effect of the highest doses just via $D_{2}$ receptor.

A similar conclusion can be drawn from our data. Bromocriptine increased water intake while, Chlorpromazine decreased it.

ICV pretreatment with Losartan 15 min before injection of Bromocriptine could significantly attenuate the inhibitory effect of Losartan on water intake and ICV pretreatment with Losartan 15 min before injection of 
Chlorpromazine significantly decreased water intake in comparison to saline-treated controls but Chlorpromazine could not change the Losartan effect.

There is some evidence to support the concept of relationship between brain angiotensin II and catecholamine systems. This interaction may participate in some central actions of Ang II such as dipsogenic behavior. It also extends to the nigrostriatal dopaminergic system, which bears $\mathrm{AT}_{1}$ receptors, both on their cell bodies in the substantia nigra presynaptically, and on their terminals in the striatum, where Ang II can markedly potentiate DA release [41]. Dopamine concentration in the ventral tegmental area (VTA) is markedly reduced in rats with low central Ang II [42]. These observations suggest that drugs which modulate central Ang II may be useful in regulating central dopaminergic activity [41]. Furthermore, data showed that angiotensin II induced vasopressin release and the AVP response to angiotensin II in the presence of dopaminergic antagonists was significantly decreased. This finding suggests that a dopaminergic mechanism may be involved in angiotensin II-induced AVP release [43]. Fitzsimones et al. demonstrated that catecholaminergic antagonists reduced the stimulatory effect of the intracranial injection of angiotensin. Other studies have shown that Ang II could stimulate dopaminergic mechanisms in water intake [44].

In summary, we have shown that the brain dopaminergic system is one of the factors controlling water intake in rats. It interacts with angiotensinergic system in the regulation of water intake. Future studies will be needed to elucidate the mechanisms underlying the interaction between dopaminergic and angiotensinergic systems.

\section{Acknowledgements}

This work was granted by Pasteur Institute of Iran and Tarbiat Moallem University.

\section{REFERENCES}

[1] A. K. Johnson and R. L. Thunhorst, "The Neuroendocrinology of Thirst and Salt Appetite: Visceral Sensory Signals and Mechanisms of Central Integration," Journal of Frontiers in Neuroendocrinology, Vol. 18, No. 3, 1997, pp. 292-353.

[2] J. Magrani, E. Silva, A. C. Ramos, R. Athanazio, M. Barbetta and J. B. Fregoneze, "Central $\mathrm{H}_{1}$ and $\mathrm{H}_{2}$ Receptor Participation in the Control of Water and Salt Intake in Rats," Physiology \& Behavior, Vol. 84, No. 2, 2004, pp. 233-243. doi:10.1016/j.physbeh.2004.11.010

[3] M. J. McKinley and A. K. Johnson, "The Physiological Regulation of Thirst and Fluid Intake," News in Physiological Sciences, Vol. 19, No. 1, 2004, pp. 1-6. doi:10.1152/nips.01470.2003

[4] A. K. Johnson, J. T. Cunningham and R. L. Thunhorst, "Integrative Role of the Lamina Terminalis in the Regu- lation of Cardiovascular and Body Fluid Homeostasis," Clinical and Experimental Pharmacology and Physiology, Vol. 23, No. 2, 1996, pp. 183-191. doi:10.1111/j.1440-1681.1996.tb02594.x

[5] E. Bagi, E. Fekete, D. Banyai and L. Lenard, "Effects of Angiotensin II and AIII Microinjections into the Zona Incerta after Intra- and Extracellular Fluid Loss," Brain Research, Vol. 1002, No. 1-2, 2004, pp. 110-119. doi:10.1016/j.brainres.2004.01.002

[6] S. M. McCann, Ka. J. Gutkows, C. R. Franci, A. L. Favaretto and R. J. Antunes, "Hypothalamic Central of Water and Salt Intake and Excretion," Brazilian Journal of Medical and Biological Research, Vol. 27, 1994, pp. 865-884.

[7] E. Gland and R. C. Ritter, "Area Postrema Lesions Increase Drinking to Angiotensin and Extra Cellular Dehydration," Physiology \& Behavior, Vol. 29, No. 5, 1982, pp. 943-947. doi:10.1016/0031-9384(82)90348-1

[8] P. C. Wong, W. A. Price, A. T. Chiu, J. V. Duncia, D. J. Carin, R. R. Wexler and A. L. Johnson and P. B. Timmermans, "Nonpeptide Angiotensin II Receptor Antagonosts," Journal of Pharmacology and Experimental Therapeutics, Vol. 252, 1990, pp. 719-725.

[9] L. J. Waldecy and R. F. Celso, "Angiotensinergi Pathway through the Media Preoptic Nucleus in the Control Ofoytocine Secretion and Water and Sodium Intake," Brain Research, Vol. 1014, No. 1-2, 2004, pp. 236-243. doi:10.1016/j.brainres.2004.03.077

[10] A. Jucaite, "Dopaminergic Modulation of Cerebral Activity and Cognitive Functions," Medicina Kaunas Lithuania, Vol. 38, No. 4, 2002, pp. 357-362.

[11] M. Puigde, X. Paez, M. A. Parada, L. Hernandez, G. Molina, E. Murzi and Q. Contreras, "Changes in Dopamine and Acetylcholine Release in the Rat Lateral Hypothalamus during Deprivation-Induced Drinking," Neuroscience Letters, Vol. 227, No. 3, 1997, pp. 153-156. doi:10.1016/S0304-3940(97)00326-1

[12] M. Le Moal and H. Simon, "Mesocorticolimbic Dopaminergic Network: Functional and Regulatory Roles," Physiological Reviews, Vol. 71, No. 1, 1991, pp. 155- 234.

[13] G. K. Pal, P. Pal and M. Rajss Moham, "Modulation of Feeding and Drinking Behavior by Catecholamines Injected into Nucleus Caudatus in Rats," Indian Journal of Physiology and Pharmacology, Vol. 45, No. 2, 2001, pp. 172-180.

[14] F. J. Gordon, M. J. Brody, G. D. Fink, J. Buggy and A. Johnson, "Role of Central Catecholamine in the Control of Blood Pressure and Drinking Behavior," Brain Research, Vol. 178, No. 1, 1979, pp. 161-173. doi:10.1016/0006-8993(79)90095-7

[15] H. Kobayashi and Y. Takei, "Mechanisms for Induction of Drinking with Special Reference to Angiotensin II," Comparative Biochemistry and Physiology Part A: Physiology, Vol. 71, No. 4, 1982, pp. 485-494. doi:10.1016/0300-9629(82)90197-9

[16] J. T. Fitzsimons and P. E. Setter, "The Relative Importance of Central nervous Catecholaminergic and Cholinergic Mechanisms in Drinking in Response to Angiotensin and Other Thirst Stimuli," Journal of Physiology, 
Vol. 250, 1975, pp. 613-631.

[17] M. A. Parada, L. Hernandez and B. G. Hoebel, "Sulpiride Injections in the Lateral Hypothalamus Induce Feeding and Drinking in Rats," Journal of Behavioral and Neuroscience Research, Vol. 30, 1988, pp. 917-923.

[18] S. Hohle, H. Spitznagel, W. Rascher, J. Culman and T. Unger, "Angiotensin $\mathrm{AT}_{1}$ Receptor-Mediated Vasopressin Release and Drinking Are Potentiated by an $\mathrm{AT}_{2}$ Receptor Antagonist," European Journal of Pharmacology, Vol. 275, No. 3, 1995, pp. 277-282. doi:10.1016/0014-2999(95)00005-6

[19] M. J. McKinley, L. Walker Lesley, T. Alexiou, A. M. Allen, D. J. Campbell, R. D. Nicolantonio, B. J. Oldfield and A. D. Denton, "Osmoregulatory Fluid Intake but Not Hypovolemic Thirst Is Intact in Mice Lacking Angiotensin," American Journal of Physiology-Regulatory, Integrative and Comparative Physiology, Vol. 294, No. 5, 2008, pp. R1533-R1543. doi:10.1152/ajpregu.00848.2007

[20] F. Qadri, T. Waldmann, A. Wolf, S. Höhle, R. Wolfgang and T. Unger, "Differential Contribution of Angiotensinergic and Cholinergic Receptors in the Hypothalamic Paraventricular Nucleus to Osmotically Induced AVP Release," Journal of Pharmacology and Experimental Therapeutics, Vol. 285, No. 3, 1998, pp. 1012-1018.

[21] M. Tham, M. K. Sim and F. R. Tang, "Location of Rennin-Angiotansin System Components in the Hypoglossal Nucleus of the Rat," Regulatory Peptides, Vol. 101, No. 1-3, 2001, pp. 51-57. doi:10.1016/S0167-0115(01)00260-9

[22] L. Grobe Justin, X. Di and D. Sigmund Curt, "An Intracellular Rennin-Angiotensin System in Neurons: Fact, Hypothesis, or Fantasy," Physiology, Vol. 23, No. 4, 2008, pp. 187-193. doi:10.1152/physiol.00002.2008

[23] Z. Pirnik, D. Jezova, J D. Mikkelsen and A. Kiss, "Xylazine Activates Oxytocinergic but Not Vasopressinergic Hypothalamic Neurons under Normal and Hyperosmotic Conditions in Rats," Neurochemistry International, Vol. 47, No. 7, 2005, pp. 458-465. doi:10.1016/j.neuint.2005.07.001

[24] J. Culman, C. Vontleyer, B. P. Penburg, W. Rascher and T. Unger, "Effects of Systemic Treatment with Irbesartan and Losartan on Central Responses to Angiotensin II conscious Normotensive Rats," European Journal of Pharmacology, Vol. 367, No. 2-3, 1999, pp. 255-265. doi:10.1016/S0014-2999(98)00983-2

[25] P. Gohlke and S. Weiss, A. Janson, W. Wienen, J. Stangier, W. Rascher, J. Culman and T. Unger, " $\mathrm{AT}_{1}$ Receptor Antagonist Telmisartan Administered Peripherally Inhibits Central Responses to Angiotensin II in Conscious rats," Pharmacology, Vol. 298, No. 1, 2001, pp. 62-70.

[26] M. J. McKinley, A. M. Allen, M. L. Mathal, C. May, R. M. McAllen, B. J. Old field and R. S. Weisinger, "Brain Angiotensin and Body Fluid Homeostasis," The Japanese Journal of Physiology, Vol. 51, No. 3, 2001, pp. 281-289. doi:10.2170/jiphysiol.51.281

[27] K. A. Al-Barazanji and R. J. Balment, "The Renal and Vascular Effects of Central Angiotensin II and Atrial Natriuretic Factor in the Anaesthetized Rat," Journal of Physiology, Vol. 423, 1990, pp. 485-493.
[28] J. A. Saydoff, P. A. Rittenhouse, M. Carnes, J. Armstrong, L. D. Van De Kar and M. S. Brownfield, "Neuroendocrine and Cardiovascular Effects of Serotonin: Selective Role of Brain Angiotensin on Vasopressin," American Journal of Physiology-Endocrinology, Vol. 270, 1996, pp. E513-E521.

[29] J. L. Lavoie, X. Liu, R. A. Bianco, T. G. Beltz, A. K. Johnson and C. D. Sigmund, "Evidence Supporting a Functional Role for Intracellular Rennin in the Brain," Hypertension, Vol. 47, 2006, pp. 461-466. doi:10.1161/01.HYP.0000203308.52919.dc

[30] E. Lazartigues, S. M. Dunlay, A. K. Loihl, P. Sinnayah, J. A. Lang, J. J. Espelund, C. D. Sibmund and R. L. Davisson, "Brain-Selective Overexpression of Angiotensin $\left(\mathrm{AT}_{1}\right)$ Receptors Causes Enhanced Cardiovascular Sensitivity in Transgenic Mice," Circulation Research, Vol. 90, 2002, pp. 617-624. doi:10.1161/01.RES.0000012460.85923.F0

[31] Y. Sagara, Y. Hirooka, M. Nozoe, K. Ito, Y. Kimura and K. Sunagawa, "Pressor Response Induced by Central Angiotensin II Is Mediated by Activation of Rho/Rho-Kinase Pathway via $\mathrm{AT}_{1}$ Receptors," Journal of Hypertension, Vol. 25, No. 2, 2007, pp. 399-406. doi:10.1097/HJH.0b013e328010b87f

[32] Q. H. Chen, M. Glenn and G. M. Toney, "AT 1 -Receptor Blockade in the Hypothalamic PVN Reduces Central Hyperosmolality-Induced Renal Sympathoexcitation," American Journal of Physiology, Vol. 281, No. 6, 2001, pp. R1844-R1853.

[33] T. Hussain and M. F. Lokhandwala, "Society for Experimental Biology and Medicine Renal Dopamine Receptors and Hypertension," Experimental Biology and Medicine, Vol. 228, No. 2, 2003, pp. 134-142.

[34] M. L. Forsling and H. Williams, "Central Effects of Dopamine on Vasopressin in the Normally Hydrated and Water-Loaded Rat," Journal of Physiology, Vol. 346, 1984, pp. 49-59.

[35] J. L. Cornish, D. P. Wilks and M. Van, "A Functional Interaction between the Mesolimbic Dopamine System and Vasopressin Release in the Regulation of Blood Pressure in Conscious Rats," Neuroscience, Vol. 81, No. 1, 1997, pp. 69-78. doi:10.1016/S0306-4522(97)00157-7

[36] M. Sakata, H. Sei, K. Toida, H. Fujihara, R. Urushihara and Y. Morita, "Mesolimbic Dopaminergic System Is Involved in Diurnal Blood Pressure Regulation," Brain Research, Vol. 22, No. 2, 2002, pp. 194-201. doi:10.1016/S0006-8993(01)03402-3

[37] M. Velasco and A. Luchsinger, "Dopamine: Pharmacologic and Therapeutic Aspects," American Journal of Therapeutics, Vol. 5, No. 1, 1998, pp. 37-43. doi:10.1097/00045391-199801000-00007

[38] M. V. Buuse, "Role of the Mesolimbic Dopamine System in Cardiovascular Homeostasis: Stimulation of the Ventral Tegmental Area Modulates the Effect of Vasopressin on Blood Pressure in Conscious Rat," Clinical and Experimental Pharmacology and Physiology, Vol. 25, No. 9, 2007, pp. 661-668. doi:10.1111/j.1440-1681.1998.tb02273.x

[39] E. Diaz, M. Silva and A. Israel, "Role of Brain Dopaminergic System in the Adrenomedullin-Induced Diuresis 
and Natriuresis," Pharmacological Research, Vol. 48, No. 5, 2003, pp. 489-496. doi:10.1016/S1043-6618(03)00186-5

[40] S. J. Hill, C. R. Ganellin, H. Timnerman, J. C. Schwartz, N. P. Shankley, J. M. Young, W. Schunack, R. Levi and H. L. Haas, "International Union of Pharmacology XIII. Classification of Histamine Receptors," Pharmacological Reviews, Vol. 49, 1997, pp. 253-278.

[41] T. A. Jenkins, A. M. Allen, S. Y. Chai, D. P. MacGregor, G. Poxinos and F. A. Mendelsohn, "Interaction of Angiotensin II with Central Dopamine," Advances in Experimental Medicine and Biology, Vol. 396, 1996, pp. 93103.

[42] B. Maul, W. Krause, K. Pankow, M. Becker, F. Gembardt,
N. Alenina, T. Walther, M. Bader and W. Siems, "Central angiotensin II Controls Alcohol Consumption via Its $\mathrm{AT}_{1}$ Receptor," FASEB Journal, Vol. 19, No. 11, 2005, pp. 1474-1481. doi:10.1096/fj.05-3742com

[43] D. P. Brooks and J. R. Claybaugh, "Role of Dopmine in the Angiotensin II-Induced Vasopressin Release in the Conscious Dehydrated Dog," Journal of Endocrinology, Vol. 94, 1982, pp. 243-249. doi:10.1677/joe.0.0940243

[44] R. S. Weisinger, J. R. Blair-West, P. Burns, A. Denton and B. Purcell, "Central Na Concentration, Na Appetite and Thirst of Sheep: Influence of Somatostatin and Losartan," American Journal of Physiology, Vol. 280, No. 3, 2001, pp. 686-694. 